\title{
Metabolic, Bioproductive and Reproductive Effects of Aquatic Exposure to Cadmium in Dish- A Review
}

\author{
Bogdan GEORGESCU ${ }^{1}$, Daniel MIERLIȚA ${ }^{2}$, Dănuț STRUȚI ${ }^{1}$, Hermina KISS ${ }^{1}$, Anca BOARU ${ }^{1 *}$ \\ ${ }^{1}$ University of Agricultural Sciences and Veterinary Medicine, Faculty of Animal Science and \\ Biotechnologies, Cluj-Napoca, Romania, EU. \\ ${ }^{2}$ Department of Animal Science, University of Oradea, Romania, EU. \\ * corresponding author: anca.boaru@usamvcluj.ro
}

Bulletin UASVM Animal Science and Biotechnologies 74(1)/ 2017

Print ISSN 1843-5262; Electronic ISSN 1843-536X

DOI:10.15835/buasvmcn-asb: 12198

\begin{abstract}
Cadmium (Cd) exposure in fish is the result of aquatic pollution with heavy metals, which is mainly caused byanthropic interventions. Rarely, Cd mobilization from natural resources takes place. Bioaccumulation in tissues and organs is a property of this heavy metal, to generate various pathological effects and major risks due to biopropagation within the human food chain. Wehereby reviewed the main circumstances and levels of exposure to Cd in the aquatic environment, and effects on growth, development and reproduction induced by its bioaccumulation in fish, as well as the possible ramifications for food security in humans.
\end{abstract}

Keywords: cadmium (Cd), fish, food, production.

\section{INTRODUCTION}

Aquatic organisms exposure to heavy metals has been extensively studied starting with the second half of the twenthieth century. Effects of exposure, the capacity of bioconcentration and bio-propagation of $\mathrm{Cd}$ within the aquatic trophic chains is of wide interest, as all these combined involve important food security risks to humans. It is well-known that aquatic organisms, particularly various fish species, consistently react to water pollution; therefore, they represent reliable bioindicators of water quality.

\section{SOURCES OF CADMIUM POLLUTION IN AQUATIC SYSTEM}

Cadmium is a common element, ubiquitous distributed in the environment in concentrations varying between $0.1-25 \mathrm{ppm}$. Cadmium concentrations depend on the nature of the rock structure of origin (Cook et al.,1995). In agricultural land areas, the high $\mathrm{Cd}$ concentrationoriginates from phosphate-rich fertilizers that may be found in concentrations up to $10-200 \mathrm{ppm}$, but also from Cd-containing pesticides and other fertilizers such as natural manure and slurries, which may contain significant amounts of Cd (Cook et al., 1995; Wuana et al., 2011).

Freshwater pollution is commonly the consequence of elutriation of agricultural soils, mine extracts deposits and industrial waste by rainfall water. The Cd load in these waters depends on the location and sources of pollution found in each area, explaining why reported concentrations may vary largely between $10-4000 \mathrm{ng} / \mathrm{mL}$ (OECD, 1996; Who, 1992). In sea and ocean waters, mean Cd concentration is $5-20 \mathrm{ng} / \mathrm{mL}$, but the level is significantly higher inindustrialized coastal areas where it may reach $100 \mathrm{ng} / \mathrm{L}$ (Cook et al., 1995; OECD, 1994). 


\section{CADMIUM BIOACCUMULATION IN FISH}

Normal ranges of $\mathrm{Cd}$ concentration in fish meat should not surpass 5-40 ppb (ATSDR, 1997). Cadmium enters the animal body by intestinal absorption in most cases or, alternatively, by branchial respiration or transdermal passage.

Several mechanisms of transdermal penetration are possible: simple diffusion, transport channels of calcium ions, aminoacids transmembrane passage and metallothioneins, which exhibit high affinity for Cd (Olsson and Hogstrand, 1987; Olsson, 1998).

From the circulation, $\mathrm{Cd}$ is bioaccumulative by the kidneys, the liver and the branchial arches (De Smet et al., 2001; Kumar et al., 2005). After 9-months exposure to $5.0 \mathrm{pg} / \mathrm{L}$ of $\mathrm{Cd}$ in the trout species Salvelinus namaycush, the highest $\mathrm{Cd}$ concentration ( $2.5 \mathrm{pg} / \mathrm{g}$ wet weight) was detected in the posterior kidney (Scherer et al., 1997).

Exposure to $\mathrm{Cd}$ stearate-containing forage (100 $\mathrm{mg} \mathrm{Cd} / \mathrm{kg}$ ) was associated in the rainbow trout (Oncorhynchus mykiss) with high Cd levels and specific histological changes in the liver and the kidney (Kumada et al., 1980).

Simultaneous exposure of fish species Liza vaigiensis and Johnius carutta to several heavy metals $(\mathrm{Cd}, \mathrm{Cr}, \mathrm{Pb}$ and $\mathrm{Ni}$ ) resulted in highest $\mathrm{Cd}$ concentrations in the liver, of $0.68 \mathrm{mg} / \mathrm{g}$ wet weight in Liza vaigiensis and $0.58 \mathrm{mg} / \mathrm{g}$ wet weight in Johnius carutta, respectively. The content of $\mathrm{Cd}$ in branchial arches was of $0.30 \mathrm{mg} / \mathrm{g}$ wet weight in Liza vaigiensis and $0.29 \mathrm{mg} / \mathrm{g}$ wet weight in Johnius carutta, respectively. The lowest $\mathrm{Cd}$ concentration was evidenced in the muscles, of $0.16 \mathrm{mg} / \mathrm{g}$ in both species. Differences in Cd concentrations between different types of tissues were highly significant $(p<0.001)$ in both species. In most cases, females presented significantly higher content of heavy metals in tissues than males, however, no statistical significance was reached (Mohsen et al., 2012).

\section{METABOLIC, BIOPRODUCTIVE AND REPRODUCTIVE EFFECTS OF CADMIUM EXPOSURE}

Both absorption rate and amount of absorbed $\mathrm{Cd}$ in Cirrhinus mrigala is potentiated by concomitant absorption of nichel (Ni), the two acting synergistically. In fact, bioaccumulation of the two heavy metals in case of simultaneous exposure is significantly higher in comparison to individual exposure to each contaminant (Palaniappan et al., 2009).

Studies on various fish species, experimentally exposed to sublethal $\mathrm{Cd}$ concentrations, indicate a reduction of food intake and significant decrease in metabolic processes rates. The silver carp, Hypophthalmichthys molitrix, when exposed to water with Cd levels of $0.01 \mathrm{mg} / \mathrm{L}$ for 96 hours resulted in significant increase of plasmatic concentrations of cortisol, lactate, glucose and red blood cells. In addition, a decrease in glycogen and muscle ATP levels was noticed and an increase in the muscle lactate concentration was obtained, the later being there after maintained constant throughout the exposure period.

The data indicate significant physiological changes in the muscle metabolism, possibly linked to alterations in gas exchanges at the branchial arches level (Zhang et al., 2013). Offspring from species Catostomus commersonii and Luxilus cornutus, when were exposed to aquatic contamination with cadmiu, have presented a significantly higher food intake compared to the control groups and the individual growth rate was with $67-100 \%$ lower. The efficiency of food conversion was below 50\% (Borgmann et al., 1986).

Exposure of crucians (Carassius auratus gibelio) to $20 \mathrm{mg} / \mathrm{L} \mathrm{Cd}$ for 15 days resulted in significant reduction fo the superoxiddismutase activity (SOD) in erythrocytes after the first day of exposure, followed by an increase in the enzymatic activity during days 7-15. The red blood cells catalase also increased after 15 days of exposure as well as the serum transaminases (GOT and GPT). At the same time, the hemoglobin level and hematocryte significantly decreased. Glucose levels constantly increased during exposure. These data suggest generation of oxidative stress and tissue lesions in exposed fish (Zikić et al., 2001).

Similar results were reported in the species Oncorhynchus mykiss exposed to sublethal $\mathrm{Cd}$ concentrations of 1 and $3 \mathrm{pg} / \mathrm{L}$, respectively, for 30 days, which resulted in a significant dose- and time-dependent increase in alkaline phosphatase and aminotranspherases. In contrast, triglycerides and cholesterol levels decreased up to exposure day 15 but raised afterwards, whereas serum glucose levels increased up to exposure day 15 and decreased thereafter reaching levels similar to those observed in controls. The total protein 
concentration levels rised, reaching at end of experiments significantly higher values in exposed animals compared to controls. Exposed trouts ingested less food and exhibited decreased growth rates (Saeed et al., 2013).

Exposure of the tench (Tinca tinca) for 3 hours to a water concentration of $\mathrm{Cd}$ of $4.5 \mathrm{mg} /$ $\mathrm{dm}^{3}$ resulted in notable changes of hematological parameters, a significant decrease in oxygen demand, a decrease in the metabolic rate and alteration of the immune response. The number of red blood cells constantly increased for 96 hours after exposure, when the experiment reached its end, whereas the white blood cell number progressively decreased without changes in the lymphocytes/neutrophiles ratio, both parameters being significantly modified in comparison to the control group. With regard to blood cells, the numbers of structural abnormalities significantly increased, for instance abnormally shaped cells, intracellular vacuolation, cell swelling and disintegration of nuclear chromatin (Witeska et al., 2006).

Exposure to $\mathrm{Cd}$ induces several effects on the endocrine status and on carbohydrates metabolism in fish. Acute effects of $0.4,0.8$ and $2.4 \mathrm{mg} / \mathrm{L}$ Cd exposure for 2, 4, 24 and 96 hours on young rainbow trout populations (Oncorhynchus mykiss) consisted of increased $\mathrm{T}_{4}$ levels and an elevation of plasma cortisol, whereas $\mathrm{T}_{3}$ concentration remained unchanged. Subacute exposure $(0.4$ and $0.8 \mathrm{mg} / \mathrm{L} \mathrm{Cd}$ ) for 1 week resulted in a decrease of liver glycogen combined to an increase in glucose and serum cortisol levels, while $\mathrm{T}_{4}$ decreased and $\mathrm{T}_{3}$ remained stable (Hontella et al., 1996).

In another study, exposure of the rainbow trout (Oncorhynchus mykiss) to sublethal concentrations of $\mathrm{Cd}$ altered the physiological state by changes in endocrine and metabolic activities, in both adults and young animals, to result in decreased calcium and low $\mathrm{T}_{3}$ and $\mathrm{T}_{4}$. Exposure of adults to 10 and $25 \mathrm{mg} / \mathrm{L} \mathrm{Cd}$ and exposure of the youth to 1 and $5 \mathrm{mg} / \mathrm{L} \mathrm{Cd}$, respectively, for 30 days resulted in a significant reduction of the liver volume and glycogen levels, in addition to a lower growth rate (Ricard et al., 1998).

Endocrine-disrupting effects of $\mathrm{Cd}$ were noticed in tilapia (Oreochromis mossambicus) exposed for 150 days to 1, 10, 50, 100 and $150 \mathrm{ppt}$ of $\mathrm{CdCl}_{2}$. Reproductive parameters such as spawns, the somato-gonadal index, reproductive hormone levels (estradiol, progesterone, testosterone) and gonadotropins (GtH-I, GtH-II) significantly differed in comparison to those seen in controls (Amutha et al., 2013). Nevertheless, each species may react differently to $\mathrm{Cd}$ exposure. Rainbow trout (Oncorhynchus mykiss) and yellow perch (Perca flavescens) adrenocortical cells cultures were exposed to $\mathrm{Cd}$ for 60 days. Cultures were stimulated with physiological stimuli such as ACTH, dbcAMP and pregnenolon, and effects on adrenal steroidogenesis and the cortisol levels were assessed. Cadmium resulted in inhibition of cortisol production, which was observed in both species but more expressed in rainbow trout cells compared to perch cells. In agreement to these study, Cd appears to affect glucocorticoid synthesis pathways at an early stage, before the biosynthesis of pregennolone (Lacroix et al., 2004). Exposure of the yellow perch (Perca flavescens) to heavy metals (Cd, $\mathrm{Zn}, \mathrm{CU}, \mathrm{Pb}$ and $\mathrm{Ni}$ ) led to changes in $\mathrm{T}_{3}$, $\mathrm{T}_{4}$ and $17 \mathrm{~b}$-estradiol levels and to an altered $\mathrm{Na}^{+} /$ $\mathrm{K}^{+}$-ATP-ase activity. The study authors concluded that longterm exposure to sublethal heavy metals contamination will change physiological functions and delay reproductive activity (L'evesque et al., 2003).

Concomitant exposure of young rainbow trout to forage with high calcium (Ca) content (e.g. 30 and $60 \mathrm{mg} \mathrm{Ca}^{2+} / \mathrm{g}$ forage in the form of $\mathrm{CaCl}_{2} \mathrm{H}_{2} \mathrm{O}$ ) and $\mathrm{Cd}\left(50 \mathrm{mg} / \mathrm{L} \mathrm{CdNO}_{3}\right)$ for 3 hours was associated to marked branchial absorption of $\mathrm{Cd}$. The data suggest that the two ions use a common transmembrane transporter and may act in a competitive manner. Under the same experimental conditions, body $\mathrm{Ca}^{2+}, \mathrm{Na}^{+}$and $\mathrm{Cl}^{-}$levels remained stable (Baldisserotto et al., 2004). A similar effect was observed after aquatic exposure of the catfish species Clarias batrachus to sublethal $\mathrm{Cd}$ concentrations ( 5 and $10 \mathrm{ppm} \mathrm{CdCl}_{2} \mathrm{H}_{2} \mathrm{O}$ ) for 45 days simultaneously to natural antioxidants such as ascorbic acid, dry garlic extract and taurine (2-aminoethansulphonic acid) at $5 \mathrm{ppm}$ in water. The presence of antioxidants significantly reduced the oxidative stress rate in exposed fish, which was demonstrated by lower levels of lipid peroxides and increased catalase and SOD activity in the liver, kidney and erythrocytes in comparison to controls. Experimental data indicate that use of natural antioxidants significantly lowered Cd levels in tissues. Ascorbic acid acted most 
efficiently, while taurine had the weakest effect (Kumar et al., 2009).

A Canadian study on the implication of pollution with heavy metals $(\mathrm{Cd}, \mathrm{Cu}$ and $\mathrm{Zn}$ ) of aquatic ecosystems on ecosystems productivity and energy efficiency in fisheries reported a threefold lower capacity of energy conversion and storage in the yellow perch (Perca flavescens) in comparison to perches originating from unpolluted systems (4.2\% vs $10.8 \%)$. This demonstrates that significantly higher energy costs are reported in fish populations exposed to heavy metals. Moreover, the adult population was increasingly represented in contaminated aquatic ecosystems, thus, suggesting reproductive problems and a high mortality rate among young individuals. Heavy metals-contaminated aquatic biocenosis featured lower numbers of population structure of species as well as simplified trophic chains to demonstrate global effects affecting the entire biocenosis (Sherwood et al., 2011).

\section{CONCLUSIONS}

Exposure to $\mathrm{Cd}$ results in morphological, biochemical and physiological changes in fish, irrespective of the fish species. All together will interfere with the metabolic rate, eventually leading to a reduced growth rate by lowering the energy efficicency at increased energy costs. Both endocrine-disrupting effects of $\mathrm{Cd}$ and $\mathrm{Cd}$ induced alterations in the immune responseexert deleterious effects on the reproductive function. As fish products and subproducts represent important components of the human diet, longterm exposure of fish to Cd may cause food insecurity in humans. Natural antioxidants and calcium may act protective by decreasing cadmium bioaccumulation in fish.

\section{REFERENCES}

1. Agency for Toxic Substances and Disease Registry (ATSDR) (1997). Draft Toxicological Profile for Cadmium, Public Health Service, U.S. Department of Health and Human Services, Atlanta, Georgia.

2. Amutha C, Subramanian P (2013). Cadmium alters the reproductive endocrine disruption and enhancement of growth in the early and adult stages of Oreochromis mossambicus. Fish Physiology and Biochemistry 39(2):351-361.

3. Baldisserotto B, Kamunde C, Matsuo A, Wood CM (2004). A protective effect of dietary calcium against acute waterborne cadmium uptake in rainbow trout. Aquat Toxicol 30; 67(1):57-73.

4. Borgmann U, Ralph KM (1986). Effects of cadmium, 2,4-dichlorophenol and pentachlorophenol on feeding, growth and particle-size-conversion efficiency of white sucker larvae and young common shiners. Arch Environ Cont Toxicol 15:473-480.

5. Cook M E, Morrow H (1995). „Anthropogenic Sources of Cadmium in Canada," National Workshop on Cadmium Transport Into Plants, Canadian Network of Toxicology Centres, Ottawa, Ontario, Canada, June 20-21, 1995.

6. De Smet H, Blust R, Moens L (2001). Cadmium-binding to transferrin in the plasma of the common carp Cyprinus carpio. Comp Biochem Physiol C Toxicol Pharmacol 128(1):45-53.

7. Hontella A, Daniel C, Ricard AC (1996). Effects of acute and subacute exposures to cadmium on interrenal and thyroid function in rainbow trout, Oncorhynchus mykiss. Aquat Toxicol 35:171-182.

8. Kumada H, Kimura S, Yokote M (1980). Accumulation and biological effects of cadmium in rainbow trout. Bull Japan Soc Sci Fish 46:97-103.

9. Kumar P, Prasad Y, Swarup D, Patra RC and Nandi D (2005). Bioaccumulation of cadmiumin fresh waterindian catfish Clarias batrachus. Proceedings of an international conference held in Lucknow (India), 14-17th November 2005.

10. Kumar P, Prasad Y, Patra AK, Ranjan R, Patra R C, Swarup D, Singh SP (2009). Ascorbic acid, garlicextract and taurine alleviate cadmium-inducedoxidativee stress in freshwater catfish (Clarias batrachus). Sci Total Environ 407:5024-5030.

11. Lacroix A, Hontela A (2004). A comparative assessment of the adrenotoxic effects of cadmium in two teleost species, rainbow trout, Oncorhynchus mykiss, and yellow perch, Perca flavescens. Aquat Toxicol 67:13-21.

12. L'evesque HM, Dorval J, Van Der Kraak GJ, Campbell PGC, Hontela, A (2003). Hormonal, morphological and physiological responses of yellow perch (Perca flavescens) to chronic environmental metal exposures. J Toxicol Environ 66:87-106.

13. Olsson PE and Hogstrand C (1987). Subcellular distribution and binding of cadmium to metallothionein in tissues of rainbow trout after exposure to $109 \mathrm{Cd}$ via the water. Environ. Toxicol Chem 6: 867-874.

14. Olsson PE (1998). Disorders associated with heavy me tal pollution. In: Fish Diseases and Disorders. Volume 2 (Noninfectious Disorders). (Eds L eatherland, J. E. and Woo, P.T.K.), CABI International, U.K. pp: 105-131.

15. Organisation for Economic Co-operation and Development (OECD) (1994). Risk Reduction Monograph No. 5: Cadmium OECD Environment Directorate, Paris, France.

16. Organisation for Economic Co-operation and Development (OECD) (1996). Report From Session F, „Sources of Cadmium in Waste," Chairman's Report of The Cadmium Workshop, ENVIMCICHEMIRD (96)1, Stockholm, Sweden, October 1995.

17. Norouzi M, Mansouri B, Hamidian AH, Zarei I, Mansouri A (2012). Metal Concentrations in Tissues of Two 
Fish Species From Qeshm Island, Iran. Bulletin of Environmental Contamination and Toxicology. November 2012, 89(5):1004-1008.

18. Palaniappan PL RM, Karthikeyan S (2009). Bioaccumulation and depuration of chromium in the selected organs and whole body tissues of freshwater fish Cirrhinus mrigala individually and in binary solutions with nickel. Journal of Environmental Sciences. 21(2):229-236.

19. Ricard AC, Daniel C, Anderson P, Hontela A (1998). Effects of subchronic exposure to cadmium chloride on endocrine and metabolic functions in rainbow trout Oncorhynchus mykiss. Arch Environ Contam Toxicol 34(4):377-81.

20. Saeed MH, Khosravian-Hemamai M, and Nematollahi A (2013). Effects of cadmium at sub-lethal concentration ongrowth and biochemical parameters in rainbow trout (Oncorhynchus mykiss). Irish Veterinary Journal 66:11.

21. Scherer E, McNicol RE, Evans RE (1997). Impairment of lake trout foraging by chronic exposure to cadmium: a black-box experiment. Aqua Toxicol 37:1-7.

22. Sherwood GD, Rasmussen JB, Rowan DJ, Brodeur J, Hontela A (2011). Bioenergetic costs of heavy metal exposure in yellow perch (Perca flavescens): in situ estimates with radiotracer (137CS) technique. Can J Fish Aquat Sci 57:441-450.
23. Witeska M, Jezierska B, Wolnieki J (2006). Respiratory and hematological responseof tench Tinca tinca (L.) to a short-term cadmium exposure. Aquacult Int 14:141-152.

24. World Health Organisation (WHO) (1992). Environmental Health Criteria 134 - Cadmium International Programme on Chemical Safety (IPCS) Monograph.

25. Wuana RA, Okieimen FE (2011). Heavy metals in contaminated soils: a review of sources,chemistry, risks and best available strategies for remediation. ISRN Ecol org/10.5402/2011/402647. Article ID 402647.

26. Zhang T, Zhang Y, Li D, Xiao T, Li J (2013). Exposure of silver carp (Hypophthalmichthys molitrix) to environmentally relevant levels of cadmium: hematology, muscle physiology, and implications for stock enhancement in the Xiangjiang River (Hunan, China). Sci China Life Sci 56(1):66-72.

27. Zikić RV, Stajn AS, Pavlović SZ, Ognjanović BI, Saićić ZS (2001). Activities of superoxide dismutase and catalase in erythrocytes and plasma transaminases of goldfish (Carassius auratus gibelio Bloch.) exposed to cadmium. Physiol Res 50(1):105-11. 